\title{
Review \\ (Dys)function Follows Form: Nucleic Acid Structure, Repeat Expansion, and Disease Pathology in FMR1 Disorders
}

\author{
Xiaonan Zhao *(1) and Karen Usdin * \\ Laboratory of Cell and Molecular Biology, National Institute of Diabetes, Digestive and Kidney Diseases, \\ National Institutes of Health, Bethesda, MD 20892, USA \\ * Correspondence: xiaonan.zhao@nih.gov (X.Z.); karenu@nih.gov (K.U.); Tel.: +1-301-451-6322 (X.Z.); \\ +1-301-496-2189 (K.U.)
}

Citation: Zhao, X.; Usdin, K. (Dys)function Follows Form: Nucleic Acid Structure, Repeat Expansion, and Disease Pathology in FMR1 Disorders. Int. J. Mol. Sci. 2021, 22, 9167. https://doi.org/10.3390/ ijms22179167

Academic Editors: Vaclav Brazda and Richard Bowater

Received: 30 July 2021

Accepted: 18 August 2021

Published: 25 August 2021

Publisher's Note: MDPI stays neutral with regard to jurisdictional claims in published maps and institutional affiliations.

\begin{abstract}
Fragile X-related disorders (FXDs), also known as FMR1 disorders, are examples of repeat expansion diseases (REDs), clinical conditions that arise from an increase in the number of repeats in a disease-specific microsatellite. In the case of FXDs, the repeat unit is CGG/CCG and the repeat tract is located in the $5^{\prime}$ UTR of the X-linked FMR1 gene. Expansion can result in neurodegeneration, ovarian dysfunction, or intellectual disability depending on the number of repeats in the expanded allele. A growing body of evidence suggests that the mutational mechanisms responsible for many REDs share several common features. It is also increasingly apparent that in some of these diseases the pathologic consequences of expansion may arise in similar ways. It has long been known that many of the disease-associated repeats form unusual DNA and RNA structures. This review will focus on what is known about these structures, the proteins with which they interact, and how they may be related to the causative mutation and disease pathology in the FMR1 disorders.
\end{abstract}

Keywords: fragile X-associated primary ovarian insufficiency (FXPOI); fragile X-associated tremor/ ataxia syndrome (FXTAS); fragile X syndrome (FXS); repeat instability; repeat expansion; chromosome fragility; RNA gain-of-function; repeat-associated non-AUG (RAN) translation; repeat-mediated gene silencing

\section{Introduction}

Repeat expansion diseases (REDs) are a group of human diseases caused by the presence of a large number of repeats in a microsatellite or short tandem repeat (STR) [1]. Unlike the microsatellite instability caused by a mismatch repair (MMR) deficiency that affects STRs genome-wide, each of these diseases results from expansion at a single disease-specific locus. While contractions of the repeat are occasionally seen, expansions predominate in both somatic and germline cells. The propensity to expand becomes apparent when the repeat number exceeds a certain critical threshold, with expansions increasing in frequency as the repeat number increases. These expansions occur in both intergenerational transmission and in the somatic cells during the lifetime of the individual. In general, for many of the diseases that are not congenital, the age at onset decreases and disease severity or disease penetrance increase with increasing repeat number [1]. As will be discussed in more detail later in this review, the characteristic features and genetic requirements for expansion in many of these diseases suggest that they may arise in similar ways. Furthermore, the pathology in many of these diseases may also arise from similar consequences of the expansion process.

More than 40 REDs have been identified to date, including Huntington's disease (HD), myotonic dystrophy type 1 (DM1), C9orf72-associated amyotrophic lateral sclerosis/frontotemporal dementia (ALS/FTD), and the FMR1 disorders, also known as the fragile X (FX)-related disorders (FXDs). In the case of the FXDs, the repeat unit is CGG/CCG and the repeat tract is located in the $5^{\prime}$ UTR of FMR1, a gene located on the long arm of the $\mathrm{X}$ chromosome (reviewed in [2]). Normal alleles have 15-45 repeats, with alleles with 
$\sim 30$ repeats being the most common. In this context the repeat tract is thought to play a role in the regulation of synthesis of the FMR1 gene product, FMRP, via the production of a protein generated from an upstream open reading frame using a near-cognate AUG codon [3]. Normal alleles are relatively stable. However, larger alleles tend to expand both in germline [4] and somatic cells [5]. Most of the historical focus has been on germline expansion, and while somatic expansion does play a role in other REDs [6,7], its role in the FXDs is unknown. Expanded repeats have paradoxical effects on expression of the FMR1 gene, with alleles with 55-200 repeats (known as premutation (PM) alleles [2,8]) being hyper-expressed, and alleles with $>200$ repeats (known as full mutation (FM) alleles $[9,10]$ ) being epigenetically silenced. The net result is that females with PM alleles are at risk of a form of female infertility known as fragile $\mathrm{X}$-associated primary ovarian insufficiency (FXPOI), and both PM males and females are at risk for a neurodegenerative condition known as fragile X-associated tremor/ataxia syndrome (FXTAS). The PM is seen in 1:200 females and 1:400 males [11]. Penetrance for FXTAS increases with age and repeat number, with $>60 \%$ of male PM carriers showing symptoms by age 70 , as compared to $\sim 16 \%$ of females [11]. FXPOI affects $~ 20-30 \%$ of PM carriers [12] and there is a non-linear relationship between repeat number and FXPOI risk that is not well understood $[13,14]$. Cells from PM carriers show splicing abnormalities [15], lamin A/C dysregulation [16], mitochondrial disfunction, and the presence of intranuclear inclusions in the brain and ovary $[17,18]$. Female PM carriers are at risk of transmitting FM alleles to their children, with the risk of doing so being related to their repeat number, the number of AGG interruptions seen at the $5^{\prime}$ end of the repeat tract, and maternal age [19]. The risk of maternal transmission of a FM allele approaches $100 \%$ when the repeat number exceeds 90 , irrespective of age or interruptions [19]. In contrast, male PM carriers do not transmit FM alleles, likely due to the tendency of long repeat tracts to contract in sperm [20]. FM alleles are seen at a frequency of $\sim 1$ in 2000 to 1 in 7000 in the general population, with a variation in prevalence seen in different populations [21]. Most males who inherit FM alleles have fragile X syndrome (FXS), the most common monogenic cause of intellectual disability and autism [22]. Females tend to be less severely affected due to the protective effect of their second $X$ chromosome. Silencing of the FM allele results in the loss of FMRP, a multi-functional protein best known for its role in negatively regulating the translation of genes important for learning and memory [23]. FM alleles are also associated with a folate-sensitive fragile site, a gap or constriction of the chromosome, coincident with the repeat [10]. Female FM fetuses also show a high frequency loss of the affected $\mathrm{X}$ chromosome, resulting in Turner syndrome [24].

As with other expansion-prone repeats, the CGG/CCG repeats responsible for the FMR1 disorders form a variety of nucleic acid secondary structures (Figure 1). These structures have the potential to interfere with many biological processes. As such, they have the potential not only to cause the mutation responsible for the FXDs, but they may also be responsible for some of the pathological consequences of the mutation. Interestingly, many targets of FMRP form G4 structures to which the protein binds [25], and FMRP has also been implicated in R-loop processing [26], thus representing other ways that noncanonical nucleic acid structures and proteins intersect in these disorders. However, in this review we will focus primarily on what is known about the DNA and RNA structures formed by the FX repeats themselves and their biological effects in the context of both expansion and disease pathology in the FMR1 disorders. 

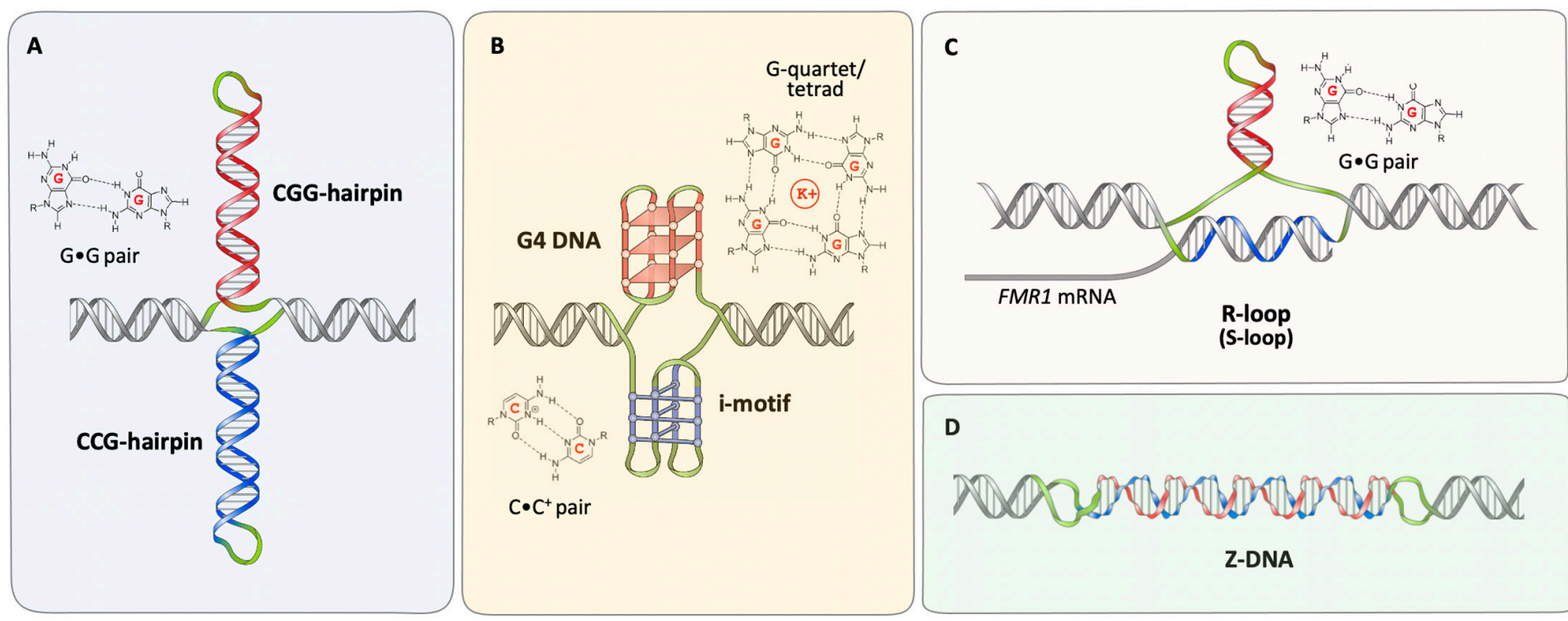

Figure 1. Generic representation of the types of DNA and RNA structures formed by FX repeats. Structures shown include hairpins formed by each strand of the repeat (A), a quadruplex or G4 DNA structure and an i-motif structure (B), an R-loop with associated hairpin formed by the non-template strand resulting in an S-loop (C) and Z-DNA (D). The CGG strand is shown in red and the CCG strand in blue. Unpaired loops regions are shown in green and the non-repetitive flanking DNA is shown in grey. Note that in addition to unpaired loop bases, some of these structures also contain non-Watson Crick base pairs or mismatches. The structures of the constituent non-canonical base interactions are shown alongside each structure.

\section{Secondary Structures Formed by FX Repeats}

Like the repeats responsible for many of the other REDs, individual DNA strands of the FX repeat can form stable hairpins containing a mixture of Watson-Crick and nonWatson-Crick base pairs or mismatches [27-32]. CGG-DNA hairpins are the most stable of the hairpins formed by different trinucleotide repeats, with a (CGG) 15 hairpin having a Tm of $75{ }^{\circ} \mathrm{C}$ in physiologically reasonable buffers [33]. In contrast, similarly sized CCG hairpins have a Tm of $30-37{ }^{\circ} \mathrm{C}$ depending on $\mathrm{pH}$, and are less stable than CGG, CTG, and CAG repeats [33]. While similar experiments have not been performed for CGG and CCG repeats, evidence from cleavage by zinc finger nucleases specific for CAG and CTG repeats provides evidence for the formation of such hairpins in mammalian cells [34]. In principle, hairpin formation by both strands of the repeat could result in a cruciform-like structure, as illustrated in Figure 1A. CGG repeats also form stable hairpins in RNA [35-37]. In addition to hairpins, the formation of intramolecular and intermolecular G4 quadruplex structures by both CGG repeat-containing DNA and RNA have been reported in some studies [27,38-45] (Figure 1B). These structures are sometimes overlooked because CGG hairpins form readily and once formed are very stable, whilst the G4 structures are only seen in the presence of $\mathrm{K}^{+}$[27]. Nonetheless, once formed these structures are stable at temperatures of $>85^{\circ} \mathrm{C}$ with physiologically reasonable $\mathrm{K}^{+}$concentrations [27]. The CCG strand of the repeat has also been shown to form a variety of intramolecular and intermolecular four-stranded structures, including i-motif structures containing intercalated $\mathrm{C} \mathrm{C}^{+}$base pairs [46-48] as illustrated in Figure 1B.

In addition to intrastrand DNA and RNA structures, the $5^{\prime}$ end of the FMR1 gene forms a stable R-loop in vivo, as illustrated in Figure 1C [49-52]. In these structures, the G-rich transcript forms a hybrid with the C-rich template strand, likely during transcription. This results in a three-stranded structure involving an RNA:DNA hybrid and a displaced DNA strand. The FMR1 R-loop extends well into the $5^{\prime}$ and $3^{\prime}$ flanking regions $[49,51]$, regions that also have a strong GC skew [53]. Non-denaturing bisulfite mapping shows that most of the cytosines on the non-template strand are resistant to bisulfite modification [49], consistent with the formation of intrastrand folded structures by the non-template strand. An R-loop containing a non-template-strand hairpin, sometimes referred to as an S-loop (for slipped hairpin R-loops), is illustrated in Figure 1C, but an R-loop with a G4 structure, a 
G-loop, is also possible. In either case the occasional modified cytosines seen on the bisulfitetreated non-template strand [49] would correspond to bases in the loops of these structures. Structures formed by the non-template strand may in turn help stabilize the R-loop [54]. Since the CGG/CCG repeats at the FMR1 locus are bidirectionally transcribed, they can also form double R-loops [55]. In addition to these inter- and intra-strand structures, there is evidence that even the CGG•CCG duplex is atypical, adopting a left-handed Z-DNA conformation as illustrated in Figure 1D [56].

\section{Repeat Expansion}

One important clue to the process that causes repeat expansion in the REDs has emerged from recent genome-wide association studies (GWAS) in different RED patient cohorts. These studies have implicated the MMR proteins MSH3, MLH1, and MLH3 as important modifiers of somatic expansion risk and/or age at onset/disease severity in many REDs [6,7,57-63]. MSH3 forms a heterodimer with MSH2 in the MutS $\beta$ complex, one of the two mismatch recognition complexes involved in MMR in mammals, while MLH1 and MLH3 form the heterodimer MutL $\gamma$, a complex that acts downstream of MutS $\beta$ in the MMR pathway [64]. Notably, single nucleotide polymorphisms associated with increased MSH3 expression are associated with increased somatic expansion in an HD patient cohort [7], suggesting that, unlike the microsatellite instability associated with certain cancers, functional MMR proteins are required for expansion. A requirement of these same proteins for repeat expansion is seen in a mouse model of FXDs as well as other mouse models of REDs (reviewed in [65,66]). A role for MMR in repeat expansion is consistent with the fact that many of the unusual structures formed by the repeats contain mismatches or regions of single-strandedness that can be bound by MutS $\beta$ and the related protein MutS $\alpha$, a heterodimer of MSH2 and MSH6 [64,67]. While GWAS studies of factors that affect germline expansion risk have not yet been performed for REDs, in the FXD mouse model it is known that the same factors that affect somatic expansion risk also affect germline expansion risk (reviewed in [65]).

However, how the MMR substrates arise is unclear. It may be that they form during strand slippage or strand displacement during replication or repair. Since expansion in many REDs can occur in non-dividing cells like oocytes and neurons $[19,68]$, repair may be a more likely source of these substrates, at least in disease-relevant cell types. One model for expansion invokes a role of base excision repair (BER) of 7,8-dihydro-8oxoguanine (8-oxoG), the most common oxidation product in DNA, with strand slippage or strand displacement during BER generating hairpin loop-outs that are bound by the MutS proteins [69]. Hairpin formation may trigger multiple rounds of BER since guanines in the loop of hairpins are susceptible to DNA damage and are less likely to be repaired [70]. A role for BER would be consistent with the fact that loss of the 7,8-dihydro-8-oxoguanine glycosylase (OGG1) leads to reduced expansion in the liver (but not in the brain or gametes) of an HD mouse model [69]. Loss of NEIL1, the other major DNA glycosylase able to remove 8-oxoG, also led to a decline in expansion in HD mouse brain [71]. GWAS studies in other REDs have not as yet identified a role for BER proteins in the expansion process [6,7,57-63]. However, this does not definitively rule out a role for BER. A role for oxidative damage in repeat expansion is supported by the observation that oxidizing agents increase repeat expansion in a mouse model of FXDs [72] and in cell models of HD [73]. However, antioxidants have no effect on an FXD mouse cell model (Miller and Usdin, unpublished observations), and only a modest effect on repeat expansions in HD mouse models $[74,75]$. Thus, spontaneous oxidative damage may not be a major contributor to expansion under normal circumstances.

Furthermore, expansions in human PM carriers require transcription of the FMR1 gene or at least for the allele to be in a region of transcriptionally competent chromatin [76]. Canonical BER has no such strict transcriptional requirement, although it is possible that transcription provides the opportunity for secondary structures to form that in turn would be predisposed to oxidative damage [70]. An alternative source of MMR substrates may be 
transcription itself, which can result in the formation of an S-loop as illustrated in Figure 1C. The S-loop may be the MMR target. It is also possible that resolution of the R-loop would then leave the template strand unable to bind its complementary strand and since the CCG-rich strand can also form hairpins, this could result in the cruciform-like double loop-out structure shown in Figures $1 \mathrm{~A}$ and $2 \mathrm{~A}$ that could also be a target for MMR.
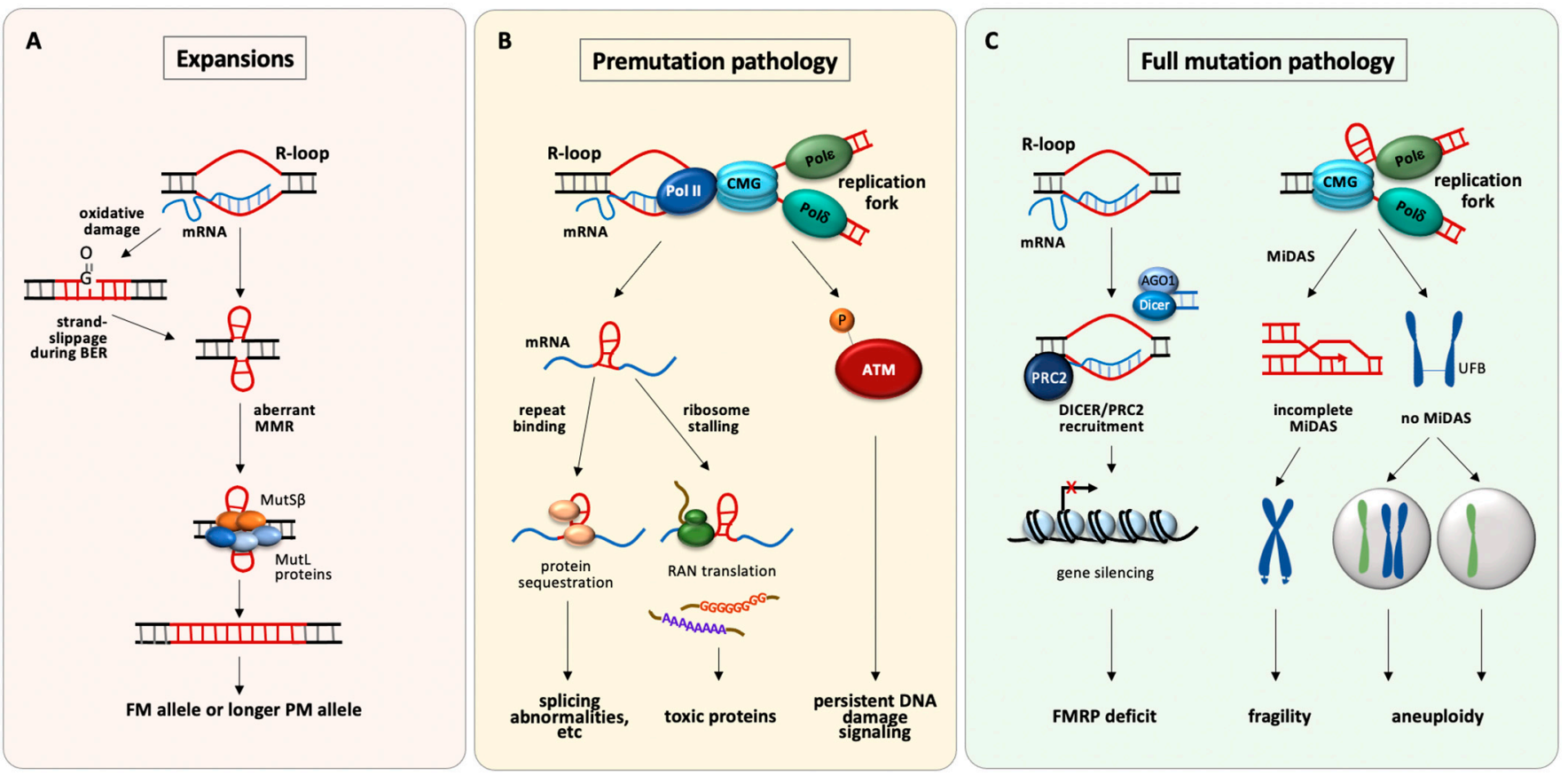

Figure 2. Models for the roles of non-canonical DNA and RNA structures in the etiology of the repeat expansion mutation and the resultant pathology seen in individuals with PM and FM alleles. (A) R-loops formed during transcription contain a region of single-stranded DNA that would be prone to oxidative damage. Base excision repair of such damage could generate loop-outs by strand-slippage or strand-displacement during repair synthesis [71,77,78]. R-loops may also facilitate the direct formation of loop-outs, first by the unpaired non-template strand when the template strand is involved in the RNA:DNA hybrid, and subsequently by the template strand after the R-loop is resolved. The loop-outs are bound by mismatch repair factors like MutS $\beta$ and MutL $\gamma$ [79-82] and are processed via a DSB [83] to generate expansions. (B) CGGhairpins in the FMR1 transcript can bind and sequester proteins [84,85] or trigger RAN translation of toxic proteins [86,87]. Persistent R-loops, perhaps exacerbated by replication-transcription collisions may result in DSBs that cause persistent DNA damage signaling [49]. (C) R-loop formation allows the recruitment of PRC2 to the FMR1 gene [88]. DICER complexes associated with dsRNA produced from the FMR1 locus [36] may also contribute to silencing by facilitating recruitment of SUV39H [89]. Secondary structures may cause stalling of the replication fork that triggers MiDAS [90]. Failure to complete MiDAS results in chromosome fragility, while failure to initiate MiDAS results in the formation of UFBs and ultimately the gain or loss of the affected X chromosome [90].

Work on a mouse model of the FXDs shows a dependence on both MutS $\beta$ and MutL $\gamma$ for repeat expansion [79-82,91], consistent with GWAS of REDs. However, other genetic modifiers of expansion risk in this mouse model suggest that the MMR protein-dependent expansion pathway differs in key ways from canonical MMR. For example, in addition to MutS $\beta$, MutS $\alpha$ also plays an important role in expansion [64], as do MutL $\alpha$ and MutL $\beta$, two other MLH1 containing complexes found in mammals [80]. MutS $\beta$ and MutS $\alpha$ are not known to act together in MMR. Neither are MutL $\gamma$ and MutL $\alpha$, while the contribution of MutL $\beta$ to MMR is unclear. Furthermore, DNA ligase IV, which is required for nonhomologous end-joining (NHEJ), a form of double-strand break (DSB) repair, protects against expansion in a mouse model of FXDs [83]. This suggests that expansion involves a DSB intermediate. It may be that a DSB results from cleavage of a double loop-out by MutL $\gamma$ which normally cuts the strand opposite a mismatch [92]. However, the details of 
this process and the downstream events that result in the generation of an expansion are still unknown.

\section{Consequences of Repeat Expansion}

\subsection{Pathology in PM Carriers}

Most work on PM pathology has focused on FXTAS rather than FXPOI. While relatively little is known about which cells are most vulnerable in these disorders, it could be that similar mechanisms act to reduce cell viability in both cases. The fact that FM carriers who make little, if any, FMR1 mRNA and FMRP, do not show FXTAS or FXPOI symptoms suggests that the CGG-repeat-containing RNA produced from PM alleles is responsible, rather than any decline in the amount of FMRP. An RNA-based pathology is supported by the demonstration that ectopic expression of the CGG-tract causes reduced cell viability [72,93-97], the production of inclusions [94,98,99], disruption of the nuclear lamin A/C architecture in neuronal cell lines [16], and neurodegeneration in both flies [94] and mice [96]. It also alters the ovarian response to gonadotropins and results in reduced fertility in mice \{Shelly, 2021\}. Interestingly, PM alleles show elevated levels of FMR1 transcription initiation [8]. R-loop formation could potentially contribute to this via its effects on chromatin decondensation [100], inhibition of binding of DNA methyltransferases [101], or the recruitment of activators including the ten-eleven translocation (TET) DNA demethylases [102]. It is also possible that the formation of hairpins or G4 DNA by the non-template strand predisposes these regions to oxidative damage, in turn increasing transcription, as has been described for the PCNA gene [103].

Several different models that invoke RNA hairpins formed by CGG-repeats have been proposed to explain PM pathology, as illustrated in Figure 2B. One such model proposes that binding of specific proteins to the CGG-repeat-containing RNA hairpins results in them being sequestered and unable to carry out their normal activities [84,104]. Numbered amongst these proteins are the splicing factor src-associated in mitosis of 68 $\mathrm{kDa}$ (Sam68) [104], and the DiGeorge syndrome critical region gene 8 (DGCR8) protein [84], a double-stranded RNA-binding protein involved in the microRNA (miRNA)-processing pathway. Consistent with a role for sequestration of these proteins, Sam68-mediated splicing abnormalities are seen in FXTAS patient cells [104], and decreased levels of mature miRNAs are seen in the brains of FXTAS patients. This is associated with decreased dendritic complexity and reduced viability of neuronal cells in culture that can be reversed by overexpression of DGCR8 [84].

Repeat-associated non-AUG (RAN) translation, a form of translation that initiates at near cognate codons upstream of or within the repeat, has also been suggested to account for PM pathology [85,86,105-107], as previously proposed for other REDs [87]. RAN translation is thought to be triggered by the stalling of the ribosome by RNA hairpins, consistent with work suggesting that kinetic barriers to the ribosome favor initiation at otherwise suboptimal initiation codons located upstream of the true initiation codon [108]. In reporter constructs with PM-sized repeat tracts, RAN translation can occur in both the sense strand producing polyglycine (FMRpolyG), polyalanine (FMRpolyA), and polyarginine (FMRpolyR)-containing proteins, and the antisense strand producing polyproline (ASFMRpolyP), polyalanine (ASFMRpolyA), and polyarginine (ASFMRpolyR)-containing proteins. FMRpolyG and FMRpolyA can be seen in intranuclear neuronal inclusions in FXTAS patients using immunochemical detection methods [109-112], and overexpression of FMRpolyG in particular is toxic in various model systems [86,107].

Interestingly, there are two other potential intersections of RNA structure and protein interactions in RAN translation. The first is related to the fact that many repeat-containing transcripts activate the double-stranded RNA-dependent protein kinase PKR $[113,114]$, presumably due to their ability to form hairpins. This results in an increase in the phosphorylation of eukaryotic translation initiation factor 2 subunit alpha (eIF2 $\alpha$ ) which in turn exacerbates RAN translation [115]. Supporting the role of PKR in RED pathology is the fact that its inhibition reduces RAN protein expression and improves disease symptoms in 
a mouse model of C9orf72 ALS/FTD [114]. Whether PKR plays a similar role in the context of CGG-repeat expansion remains to be seen. The repeats did not cause significant PKR activation in a tissue culture model [36]; however, whether this is due to the cell type used or the level of CGG-RNA produced is unclear. The second intersection with RNA structure is the demonstration that FMRpolyG binds CGG-RNA quadruplex structures in vitro, with evidence of G4 RNA promoting the liquid-to-solid transition and aggregate formation of FMRpolyG in a FXTAS mouse model [45]. However, overexpression of FMRpolyG is not always associated with FXTAS pathology in mice [116]. Furthermore, FMRpolyG is not detected by mass spectroscopy of brain extracts of FXTAS patients [117] and is only present at very low levels in inclusions isolated from such patients [17]. This raises the possibility that despite the immunological detection of these proteins in patient samples, their concentration may be too low to account for the pathology observed in PM carriers.

In addition to PKR activation by the repeat-containing RNA hairpins, elevated type 1 interferon (IFN) signaling is seen in C9orf72 ALS/FTD [118]. This process, like PKR activation, is part of the normal cellular response to double-stranded RNAs. In ALS/FTD it is associated with sterile inflammation and neuronal death. Cell death can be suppressed by inhibitors of Janus kinase, a key component of the major signaling pathway activated by IFNs but not by PKR inhibitors [118]. Whether a similar effect is seen for the CGG-RNA hairpins in PM carriers remains to be seen.

R-loop formation at the FMR1 locus has also been proposed as a source of pathology in PM carriers $[49,119]$ as illustrated in Figure 2B. R-loops are prone to single-stranded breaks and DSBs resulting from clustered single-stranded breaks [120]. Hyperphosphorylation of ataxia-telangiectasia mutated kinase (ATM), a consequence of DSBs, is seen in FXTAS cell and animal models, and $\gamma \mathrm{H} 2 \mathrm{AX}$, a marker of double-strand breaks, is present in nuclear inclusions in FXTAS patient tissue [17,97]. However, while mutations that affect R-loop levels genome-wide are associated with a variety of neurodegenerative diseases [121], given the prevalence of R-loops in the genome it is unclear whether the addition of a single, albeit a large and stable, R-loop at a PM allele would be sufficient to trigger neuronal cell death.

In addition to pathology characteristic of PM carriers, many carriers of large PM alleles, or rare FM alleles that do not become silenced, show reduced levels of FMRP that could contribute to some of the symptoms seen in this population [122,123]. The reduced FMRP levels are thought to be due to the stalling of the $40 \mathrm{~S}$ ribosomal subunit by the hairpin formed by the repeats in the $5^{\prime}$ UTR of the FMR1 transcript $[122,124]$.

\subsection{Pathology in FM Carriers}

\subsubsection{FMR1 Gene Silencing}

The $5^{\prime}$ end of the FMR1 gene in FM carriers is epigenetically modified, resulting in gene silencing and an absence or deficiency in FMRP. In FM carriers the DNA in this region of the gene is hypermethylated and associated with modified histones typical of heterochromatin, including histone $\mathrm{H} 3$ trimethylated at lysine 27 (H3K27Me3) [125]. H3K27Me3 is deposited by the polycomb repressive complex 2 (PRC2). R-loops are important for PRC2mediated gene silencing at several loci [88]. PRC2 binds to R-loops directly and drives R-loop production in Drosophila [126]. PRC2 has also been reported to bind to G-rich RNA and to G4-forming RNA sequences in particular [127]. R-loops have also been implicated in silencing in both FXS and a related RED, Friedreich ataxia [52]. The FMR1 transcript is important for recruiting PRC2 to the $5^{\prime}$ end of FM alleles that have been reactivated with 5-deazadeoxycytidine (AZA), a DNA methyltransferase inhibitor [125]. Inhibition of PRC2 or blocking its recruitment to the FMR1 5' UTR prevents H3K27 trimethylation at this locus [50]. This in turn prevents the remethylation and resilencing of FM alleles that typically occur after AZA is withdrawn [50,125]. These data would be consistent with a model in which PRC2 binds to the $5^{\prime}$ end of the FMR1 transcript, while the transcript is also simultaneously bound to the $5^{\prime}$ end of the FMR1 gene via an R-loop. This would tether PRC2 in the vicinity of the FMR1 promoter, as illustrated in Figure 2C. PRC2-mediated H3K27 
trimethylation is favored by loss of marks of active chromatin [128-130]. This loss could be triggered by R-loop formation itself via increased transcription termination $[53,131]$, or as a downstream consequence of the induction of DNA damage at R-loops [132,133]. Silencing has traditionally been considered to occur when the repeat number exceeds 200 based on data from Southern blotting; however, higher-resolution techniques like capillary electrophoresis suggest that the threshold may be higher than this [134]. What triggers the transition from the hyper-expressed state to the silenced state is unknown and the role of an R-loop in gene silencing of FM alleles seems paradoxical given its proposed roles in hyperexpression of PM alleles. However, there are many reports of similar paradoxical effects of R-loops in the literature (see [135] for a good recent discussion). The R-loop formed by an FM allele while it was still transcriptionally active would be more stable than an R-loop formed on a PM allele. As such the R-loops formed on FM alleles may form a more effective block to transcription elongation. This would result in a larger drop in H3K36me3 levels, which in turn would favor H3K27 trimethylation.

Members of the argonaute protein family and the endoribonuclease DICER1, proteins that are important for RNA-induced gene silencing via the small interfering RNA (siRNA) pathway, have also been suggested to play a role in FMR1 gene resilencing [136]. This presumably reflects a role for double-stranded RNA in the silencing process. However, whether the source of double-stranded RNA is the RNA hairpin formed by the FX repeats or the product of the annealing of the FMR1 transcript and an antisense transcript from this locus [137] is unclear. DICER-mediated gene silencing is thought to be accomplished via SUV39H-mediated trimethylation of H3K9 [89]. Since inhibitors of H3K9 methylation [138] and H3K27 trimethylation [50] delay resilencing after AZA treatment, methylation at both residues might be involved in restoring DNA methylation at this locus.

\subsubsection{Chromosome Fragility}

Fragile sites (FSs) are breaks or gaps that are visible in otherwise condensed chromosomes in metaphase spreads of cells treated with different classes of replication inhibitors [139]. They are thought to represent regions of the genome that are difficult to replicate. In the case of the FMR1 locus, expression of the fragile site, FRAXA, is induced by folate-stress that causes nucleotide pool imbalances [140]. CGG repeats are known to be difficult to replicate both in vitro [27] and in vivo [141], and replication stalling is seen at the $5^{\prime}$ end of the endogenous FMR1 gene [142]. Given the ability of CGG-repeat structures to block DNA synthesis in vitro [27], these structures could account for the replication difficulty shown in Figure 2C. The formation of a block to the replication fork is consistent with the fact that FM alleles are prone to mitotic DNA synthesis (MiDAS) when subjected to folate-stress. MiDAS is thought to be a form of break-induced replication (BIR), a salvage pathway involved in the processing of stalled replication forks to allow replication of the chromosome to be completed [90]. Suppression of MiDAS prevents chromosome fragility, but alleles that fail to initiate BIR at all are associated with high levels of ultrafine bridges (UFBs), anaphase bridges involving single-stranded regions of DNA that are histone-free [46]. Failure to resolve these UFBs results in non-disjunction of the chromosomes and subsequent aneuploidy [90] that may account for the high frequency of Turner syndrome observed in female carriers of FM alleles [24].

Replication difficulties may also account for the fact that male PM carriers do not transmit FM alleles to their children since, unlike oocytes which are post-mitotic, male gametes undergo multiple rounds of replication prior to fertilization. As such, there may be selective pressure for smaller alleles in males that is not seen in females.

\section{Concluding Remarks}

While the ability of the FX repeats to form secondary structures of various sorts has been known for some time, work in recent years has begun to identify ways to target these structures or the downstream consequences of these structures, so as to ameliorate their effects. For example, CCG-repeat-containing antisense oligonucleotides (ASOs) reduce 
R-loop formation and ameliorate some of the downstream consequences of the formation of RNA hairpins [143]. Small molecules that target CGG-RNA hairpins have also been shown to have beneficial effects in cell and mouse models of the PM [144-146]. Additionally, the ability of PKR to promote RAN translation can be inhibited by metformin [114], a widely used oral hypoglycemic agent used to treat type 2 diabetes. Thus, an understanding of the secondary structures formed by disease-associated repeats and their downstream consequences is beginning to reveal therapeutic opportunities that may be useful for treating these disorders.

Funding: The APC was made possible by funding to KU (1ZIADK057808) from the Intramural program of the NIDDK, National Institutes of Health, USA.

Conflicts of Interest: The authors declare no conflict of interest.

\section{References}

1. Paulson, H. Repeat expansion diseases. Handb. Clin. Neurol. 2018, 147, 105-123. [CrossRef] [PubMed]

2. Loesch, D.; Hagerman, R. Unstable mutations in the FMR1 gene and the phenotypes. Adv. Exp. Med. Biol. 2012, 769, 78-114. [CrossRef] [PubMed]

3. Rodriguez, C.M.; Wright, S.E.; Kearse, M.G.; Haenfler, J.M.; Flores, B.N.; Liu, Y.; Ifrim, M.F.; Glineburg, M.R.; Krans, A.; JafarNejad, P.; et al. A native function for RAN translation and CGG repeats in regulating fragile X protein synthesis. Nat. Neurosci. 2020, 23, 386-397. [CrossRef] [PubMed]

4. Nolin, S.L.; Glicksman, A.; Tortora, N.; Allen, E.; Macpherson, J.; Mila, M.; Vianna-Morgante, A.M.; Sherman, S.L.; Dobkin, C.; Latham, G.J.; et al. Expansions and contractions of the FMR1 CGG repeat in 5508 transmissions of normal, intermediate, and premutation alleles. Am. J. Med. Genet. A 2019, 179, 1148-1156. [CrossRef] [PubMed]

5. Lokanga, R.A.; Entezam, A.; Kumari, D.; Yudkin, D.; Qin, M.; Smith, C.B.; Usdin, K. Somatic expansion in mouse and human carriers of fragile X premutation alleles. Hum. Mutat. 2013, 34, 157-166. [CrossRef]

6. Ciosi, M.; Maxwell, A.; Cumming, S.A.; Hensman Moss, D.J.; Alshammari, A.M.; Flower, M.D.; Durr, A.; Leavitt, B.R.; Roos, R.A.C.; Team, T.-H.; et al. A genetic association study of glutamine-encoding DNA sequence structures, somatic CAG expansion, and DNA repair gene variants, with Huntington disease clinical outcomes. EBioMedicine 2019, 48, 568-580. [CrossRef]

7. Genetic Modifiers of Huntington's Disease Consortium. CAG Repeat Not Polyglutamine Length Determines Timing of Huntington's Disease Onset. Cell 2019, 178, 887-900.e814. [CrossRef]

8. Tassone, F.; Hagerman, R.J.; Taylor, A.K.; Gane, L.W.; Godfrey, T.E.; Hagerman, P.J. Elevated levels of FMR1 mRNA in carrier males: A new mechanism of involvement in the fragile-X syndrome. Am. J. Hum. Genet. 2000, 66, 6-15. [CrossRef] [PubMed]

9. Fu, Y.H.; Kuhl, D.P.; Pizzuti, A.; Pieretti, M.; Sutcliffe, J.S.; Richards, S.; Verkerk, A.J.; Holden, J.J.; Fenwick, R.G., Jr.; Warren, S.T.; et al. Variation of the CGG repeat at the fragile X site results in genetic instability: Resolution of the Sherman paradox. Cell 1991, 67, 1047-1058. [CrossRef]

10. Verkerk, A.J.; Pieretti, M.; Sutcliffe, J.S.; Fu, Y.H.; Kuhl, D.P.; Pizzuti, A.; Reiner, O.; Richards, S.; Victoria, M.F.; Zhang, F.P.; et al. Identification of a gene (FMR-1) containing a CGG repeat coincident with a breakpoint cluster region exhibiting length variation in fragile X syndrome. Cell 1991, 65, 905-914. [CrossRef]

11. Hagerman, R.; Hagerman, P. Fragile X-associated tremor/ataxia syndrome: Pathophysiology and management. Curr. Opin. Neurol. 2021, 34, 541-546. [CrossRef] [PubMed]

12. Allen, E.G.; Charen, K.; Hipp, H.S.; Shubeck, L.; Amin, A.; He, W.; Hunter, J.E.; Sherman, S.L. Clustering of comorbid conditions among women who carry an FMR1 premutation. Genet. Med. 2020, 22, 758-766. [CrossRef]

13. Ennis, S.; Ward, D.; Murray, A. Nonlinear association between CGG repeat number and age of menopause in FMR1 premutation carriers. Eur. J. Hum. Genet. 2006, 14, 253-255. [CrossRef] [PubMed]

14. Sullivan, A.K.; Marcus, M.; Epstein, M.P.; Allen, E.G.; Anido, A.E.; Paquin, J.J.; Yadav-Shah, M.; Sherman, S.L. Association of FMR1 repeat size with ovarian dysfunction. Hum. Reprod. 2005, 20, 402-412. [CrossRef] [PubMed]

15. Tseng, E.; Tang, H.T.; AlOlaby, R.R.; Hickey, L.; Tassone, F. Altered expression of the FMR1 splicing variants landscape in premutation carriers. Biochim. Biophys. Acta Gene Regul. Mech. 2017, 1860, 1117-1126. [CrossRef]

16. Arocena, D.G.; Iwahashi, C.K.; Won, N.; Beilina, A.; Ludwig, A.L.; Tassone, F.; Schwartz, P.H.; Hagerman, P.J. Induction of inclusion formation and disruption of lamin A/C structure by premutation CGG-repeat RNA in human cultured neural cells. Hum. Mol. Genet. 2005, 14, 3661-3671. [CrossRef]

17. Iwahashi, C.K.; Yasui, D.H.; An, H.J.; Greco, C.M.; Tassone, F.; Nannen, K.; Babineau, B.; Lebrilla, C.B.; Hagerman, R.J.; Hagerman, P.J. Protein composition of the intranuclear inclusions of FXTAS. Brain 2006, 129, 256-271. [CrossRef]

18. Ma, L.; Herren, A.W.; Espinal, G.; Randol, J.; McLaughlin, B.; Martinez-Cerdeno, V.; Pessah, I.N.; Hagerman, R.J.; Hagerman, P.J. Composition of the Intranuclear Inclusions of Fragile X-associated Tremor/Ataxia Syndrome. Acta Neuropathol. Commun. 2019, 7, 143. [CrossRef] 
19. Yrigollen, C.M.; Martorell, L.; Durbin-Johnson, B.; Naudo, M.; Genoves, J.; Murgia, A.; Polli, R.; Zhou, L.; Barbouth, D.; Rupchock, A.; et al. AGG interruptions and maternal age affect FMR1 CGG repeat allele stability during transmission. J. Neurodev. Disord. 2014, 6, 24. [CrossRef]

20. Reyniers, E.; Vits, L.; De Boulle, K.; Van Roy, B.; Van Velzen, D.; de Graaff, E.; Verkerk, A.J.; Jorens, H.Z.; Darby, J.K.; Oostra, B.; et al. The full mutation in the FMR-1 gene of male fragile X patients is absent in their sperm. Nat. Genet. 1993, 4, 143-146. [CrossRef] [PubMed]

21. Lozano, R.; Azarang, A.; Wilaisakditipakorn, T.; Hagerman, R.J. Fragile X syndrome: A review of clinical management. Intractable Rare Dis. Res. 2016, 5, 145-157. [CrossRef] [PubMed]

22. Hagerman, R.J.; Berry-Kravis, E.; Hazlett, H.C.; Bailey, D.B., Jr.; Moine, H.; Kooy, R.F.; Tassone, F.; Gantois, I.; Sonenberg, N.; Mandel, J.L.; et al. Fragile X syndrome. Nat. Rev. Dis. Primers 2017, 3, 17065. [CrossRef]

23. Richter, J.D.; Zhao, X. The molecular biology of FMRP: New insights into fragile X syndrome. Nat. Rev. Neurosci. 2021, 22, 209-222. [CrossRef] [PubMed]

24. Dobkin, C.; Radu, G.; Ding, X.H.; Brown, W.T.; Nolin, S.L. Fragile X prenatal analyses show full mutation females at high risk for mosaic Turner syndrome: Fragile X leads to chromosome loss. Am. J. Med. Genet. A 2009, 149A, 2152-2157. [CrossRef] [PubMed]

25. Darnell, J.C.; Jensen, K.B.; Jin, P.; Brown, V.; Warren, S.T.; Darnell, R.B. Fragile X mental retardation protein targets G quartet mRNAs important for neuronal function. Cell 2001, 107, 489-499. [CrossRef]

26. Chakraborty, A.; Jenjaroenpun, P.; Li, J.; El Hilali, S.; McCulley, A.; Haarer, B.; Hoffman, E.A.; Belak, A.; Thorland, A.; Hehnly, H.; et al. Replication stress induces global chromosome breakage in the fragile X genome. Cell Rep. 2021, 34, 108838. [CrossRef] [PubMed]

27. Usdin, K.; Woodford, K.J. CGG repeats associated with DNA instability and chromosome fragility form structures that block DNA synthesis in vitro. Nucleic Acids Res. 1995, 23, 4202-4209. [CrossRef]

28. Mitas, M.; Yu, A.; Dill, J.; Haworth, I.S. The trinucleotide repeat sequence d(CGG)15 forms a heat-stable hairpin containing Gsyn. Ganti base pairs. Biochemistry 1995, 34, 12803-12811. [CrossRef]

29. Yu, A.; Barron, M.D.; Romero, R.M.; Christy, M.; Gold, B.; Dai, J.; Gray, D.M.; Haworth, I.S.; Mitas, M. At physiological pH, $\mathrm{d}(\mathrm{CCG}) 15$ forms a hairpin containing protonated cytosines and a distorted helix. Biochemistry 1997, 36, 3687-3699. [CrossRef] [PubMed]

30. Nadel, Y.; Weisman-Shomer, P.; Fry, M. The fragile X syndrome single strand d(CGG)n nucleotide repeats readily fold back to form unimolecular hairpin structures. J. Biol. Chem. 1995, 270, 28970-28977. [CrossRef] [PubMed]

31. Chen, X.; Mariappan, S.V.; Catasti, P.; Ratliff, R.; Moyzis, R.K.; Laayoun, A.; Smith, S.S.; Bradbury, E.M.; Gupta, G. Hairpins are formed by the single DNA strands of the fragile X triplet repeats: Structure and biological implications. Proc. Natl. Acad. Sci. USA 1995, 92, 5199-5203. [CrossRef]

32. Gacy, A.M.; Goellner, G.; Juranic, N.; Macura, S.; McMurray, C.T. Trinucleotide repeats that expand in human disease form hairpin structures in vitro. Cell 1995, 81, 533-540. [CrossRef]

33. Mitas, M. Trinucleotide repeats associated with human disease. Nucleic Acids Res. 1997, 25, 2245-2254. [CrossRef] [PubMed]

34. Liu, G.; Chen, X.; Bissler, J.J.; Sinden, R.R.; Leffak, M. Replication-dependent instability at (CTG) x (CAG) repeat hairpins in human cells. Nat. Chem. Biol. 2010, 6, 652-659. [CrossRef]

35. Zumwalt, M.; Ludwig, A.; Hagerman, P.J.; Dieckmann, T. Secondary structure and dynamics of the r(CGG) repeat in the mRNA of the fragile X mental retardation 1 (FMR1) gene. RNA Biol. 2007, 4, 93-100. [CrossRef] [PubMed]

36. Handa, V.; Saha, T.; Usdin, K. The fragile X syndrome repeats form RNA hairpins that do not activate the interferon-inducible protein kinase, PKR, but are cut by Dicer. Nucleic Acids Res. 2003, 31, 6243-6248. [CrossRef]

37. Sobczak, K.; de Mezer, M.; Michlewski, G.; Krol, J.; Krzyzosiak, W.J. RNA structure of trinucleotide repeats associated with human neurological diseases. Nucleic Acids Res. 2003, 31, 5469-5482. [CrossRef] [PubMed]

38. Khateb, S.; Weisman-Shomer, P.; Hershco, I.; Loeb, L.A.; Fry, M. Destabilization of tetraplex structures of the fragile X repeat sequence (CGG)n is mediated by homolog-conserved domains in three members of the hnRNP family. Nucleic Acids Res. 2004, 32, 4145-4154. [CrossRef] [PubMed]

39. Khateb, S.; Weisman-Shomer, P.; Hershco-Shani, I.; Ludwig, A.L.; Fry, M. The tetraplex (CGG)n destabilizing proteins hnRNP A2 and CBF-A enhance the in vivo translation of fragile X premutation mRNA. Nucleic Acids Res. 2007, 35, 5775-5788. [CrossRef]

40. Weisman-Shomer, P.; Cohen, E.; Fry, M. Distinct domains in the CArG-box binding factor A destabilize tetraplex forms of the fragile X expanded sequence d(CGG)n. Nucleic Acids Res. 2002, 30, 3672-3681. [CrossRef] [PubMed]

41. Weisman-Shomer, P.; Cohen, E.; Hershco, I.; Khateb, S.; Wolfovitz-Barchad, O.; Hurley, L.H.; Fry, M. The cationic porphyrin TMPyP4 destabilizes the tetraplex form of the fragile X syndrome expanded sequence d(CGG)n. Nucleic Acids Res. 2003, 31, 3963-3970. [CrossRef] [PubMed]

42. Kettani, A.; Kumar, R.A.; Patel, D.J. Solution structure of a DNA quadruplex containing the fragile X syndrome triplet repeat. J. Mol. Biol. 1995, 254, 638-656. [CrossRef] [PubMed]

43. Malgowska, M.; Gudanis, D.; Kierzek, R.; Wyszko, E.; Gabelica, V.; Gdaniec, Z. Distinctive structural motifs of RNA Gquadruplexes composed of AGG, CGG and UGG trinucleotide repeats. Nucleic Acids Res. 2014, 42, 10196-10207. [CrossRef] [PubMed]

44. Binas, O.; Bessi, I.; Schwalbe, H. Structure Validation of G-Rich RNAs in Noncoding Regions of the Human Genome. ChemBioChem 2020, 21, 1656-1663. [CrossRef] 
45. Asamitsu, S.; Yabuki, Y.; Ikenoshita, S.; Kawakubo, K.; Kawasaki, M.; Usuki, S.; Nakayama, Y.; Adachi, K.; Kugoh, H.; Ishii, K.; et al. CGG repeat RNA G-quadruplexes interact with FMRpolyG to cause neuronal dysfunction in fragile X-related tremor/ataxia syndrome. Sci. Adv. 2021, 7. [CrossRef]

46. Chen, Y.W.; Satange, R.; Wu, P.C.; Jhan, C.R.; Chang, C.K.; Chung, K.R.; Waring, M.J.; Lin, S.W.; Hsieh, L.C.; Hou, M.H. Co(II)(Chromomycin)(2) Complex Induces a Conformational Change of CCG Repeats from i-Motif to Base-Extruded DNA Duplex. Int. J. Mol. Sci. 2018, 19, 2796. [CrossRef] [PubMed]

47. Yang, B.; Rodgers, M.T. Base-pairing energies of proton-bound heterodimers of cytosine and modified cytosines: Implications for the stability of DNA i-motif conformations. J. Am. Chem. Soc. 2014, 136, 282-290. [CrossRef]

48. Fojtik, P.; Vorlickova, M. The fragile X chromosome (GCC) repeat folds into a DNA tetraplex at neutral pH. Nucleic Acids Res. 2001, 29, 4684-4690. [CrossRef]

49. Loomis, E.W.; Sanz, L.A.; Chedin, F.; Hagerman, P.J. Transcription-associated R-loop formation across the human FMR1 CGGrepeat region. PLoS Genet. 2014, 10, e1004294. [CrossRef]

50. Kumari, D.; Usdin, K. Sustained expression of FMR1 mRNA from reactivated fragile X syndrome alleles after treatment with small molecules that prevent trimethylation of H3K27. Hum. Mol. Genet. 2016, 25, 3689-3698. [CrossRef]

51. Abu Diab, M.; Mor-Shaked, H.; Cohen, E.; Cohen-Hadad, Y.; Ram, O.; Epsztejn-Litman, S.; Eiges, R. The G-rich Repeats in FMR1 and C9orf72 Loci Are Hotspots for Local Unpairing of DNA. Genetics 2018, 210, 1239-1252. [CrossRef]

52. Groh, M.; Lufino, M.M.; Wade-Martins, R.; Gromak, N. R-loops associated with triplet repeat expansions promote gene silencing in Friedreich ataxia and fragile $\mathrm{X}$ syndrome. PLoS Genet. 2014, 10, e1004318. [CrossRef]

53. Ginno, P.A.; Lim, Y.W.; Lott, P.L.; Korf, I.; Chedin, F. GC skew at the $5^{\prime}$ and $3^{\prime}$ ends of human genes links R-loop formation to epigenetic regulation and transcription termination. Genome Res. 2013, 23, 1590-1600. [CrossRef]

54. De Magis, A.; Manzo, S.G.; Russo, M.; Marinello, J.; Morigi, R.; Sordet, O.; Capranico, G. DNA damage and genome instability by G-quadruplex ligands are mediated by R loops in human cancer cells. Proc. Natl. Acad. Sci. USA 2019, 116, 816-825. [CrossRef] [PubMed]

55. Reddy, K.; Tam, M.; Bowater, R.P.; Barber, M.; Tomlinson, M.; Nichol Edamura, K.; Wang, Y.H.; Pearson, C.E. Determinants of R-loop formation at convergent bidirectionally transcribed trinucleotide repeats. Nucleic Acids Res. 2011, 39, 1749-1762. [CrossRef] [PubMed]

56. Renciuk, D.; Kypr, J.; Vorlickova, M. CGG repeats associated with fragile X chromosome form left-handed Z-DNA structure. Biopolymers 2011, 95, 174-181. [CrossRef] [PubMed]

57. Genetic Modifiers of Huntington's Disease Consortium. Identification of Genetic Factors that Modify Clinical Onset of Huntington's Disease. Cell 2015, 162, 516-526. [CrossRef]

58. Moss, D.J.H.; Pardinas, A.F.; Langbehn, D.; Lo, K.; Leavitt, B.R.; Roos, R.; Durr, A.; Mead, S.; TRACK-HD Investigators; REGISTRY Investigators; et al. Identification of genetic variants associated with Huntington's disease progression: A genome-wide association study. Lancet Neurol. 2017, 16, 701-711. [CrossRef]

59. Lee, J.M.; Chao, M.J.; Harold, D.; Abu Elneel, K.; Gillis, T.; Holmans, P.; Jones, L.; Orth, M.; Myers, R.H.; Kwak, S.; et al. A modifier of Huntington's disease onset at the MLH1 locus. Hum. Mol. Genet. 2017, 26, 3859-3867. [CrossRef]

60. Bettencourt, C.; Hensman-Moss, D.; Flower, M.; Wiethoff, S.; Brice, A.; Goizet, C.; Stevanin, G.; Koutsis, G.; Karadima, G.; Panas, M.; et al. DNA repair pathways underlie a common genetic mechanism modulating onset in polyglutamine diseases. Ann. Neurol. 2016, 79, 983-990. [CrossRef]

61. Goold, R.; Flower, M.; Moss, D.H.; Medway, C.; Wood-Kaczmar, A.; Andre, R.; Farshim, P.; Bates, G.P.; Holmans, P.; Jones, L.; et al. FAN1 modifies Huntington's disease progression by stabilizing the expanded HTT CAG repeat. Hum. Mol. Genet. 2019, 28, 650-661. [CrossRef] [PubMed]

62. Morales, F.; Vasquez, M.; Santamaria, C.; Cuenca, P.; Corrales, E.; Monckton, D.G. A polymorphism in the MSH3 mismatch repair gene is associated with the levels of somatic instability of the expanded CTG repeat in the blood DNA of myotonic dystrophy type 1 patients. DNA Repair (Amst) 2016, 40, 57-66. [CrossRef] [PubMed]

63. Holmans, P.A.; Massey, T.H.; Jones, L. Genetic modifiers of Mendelian disease: Huntington's disease and the trinucleotide repeat disorders. Hum. Mol. Genet. 2017, 26, R83-R90. [CrossRef] [PubMed]

64. Zhao, X.N.; Lokanga, R.; Allette, K.; Gazy, I.; Wu, D.; Usdin, K. A MutSbeta-Dependent Contribution of MutSalpha to Repeat Expansions in Fragile X Premutation Mice? PLoS Genet. 2016, 12, e1006190. [CrossRef] [PubMed]

65. Zhao, X.; Kumari, D.; Miller, C.J.; Kim, G.Y.; Hayward, B.; Vitalo, A.G.; Pinto, R.M.; Usdin, K. Modifiers of Somatic Repeat Instability in Mouse Models of Friedreich Ataxia and the Fragile X-Related Disorders: Implications for the Mechanism of Somatic Expansion in Huntington's Disease. J. Huntingt. Dis. 2021, 10, 149-163. [CrossRef] [PubMed]

66. Wheeler, V.C.; Dion, V. Modifiers of CAG/CTG Repeat Instability: Insights from Mammalian Models. J. Huntingt. Dis. 2021, 10, 123-148. [CrossRef] [PubMed]

67. Owen, B.A.; Yang, Z.; Lai, M.; Gajec, M.; Badger, J.D., 2nd; Hayes, J.J.; Edelmann, W.; Kucherlapati, R.; Wilson, T.M.; McMurray, C.T. (CAG)(n)-hairpin DNA binds to Msh2-Msh3 and changes properties of mismatch recognition. Nat. Struct. Mol. Biol. 2005, 12, 663-670. [CrossRef]

68. Shelbourne, P.F.; Keller-McGandy, C.; Bi, W.L.; Yoon, S.R.; Dubeau, L.; Veitch, N.J.; Vonsattel, J.P.; Wexler, N.S.; Group, U.S.-V.C.R.; Arnheim, N.; et al. Triplet repeat mutation length gains correlate with cell-type specific vulnerability in Huntington disease brain. Hum. Mol. Genet. 2007, 16, 1133-1142. [CrossRef] 
69. Kovtun, I.V.; Johnson, K.O.; McMurray, C.T. Cockayne syndrome B protein antagonizes OGG1 in modulating CAG repeat length in vivo. Aging 2011, 3, 509-514. [CrossRef]

70. Jarem, D.A.; Wilson, N.R.; Delaney, S. Structure-dependent DNA damage and repair in a trinucleotide repeat sequence. Biochemistry 2009, 48, 6655-6663. [CrossRef]

71. Mollersen, L.; Rowe, A.D.; Illuzzi, J.L.; Hildrestrand, G.A.; Gerhold, K.J.; Tveteras, L.; Bjolgerud, A.; Wilson, D.M., 3rd; Bjoras, M.; Klungland, A. Neil1 is a genetic modifier of somatic and germline CAG trinucleotide repeat instability in R6/1 mice. Hum. Mol. Genet. 2012, 21, 4939-4947. [CrossRef]

72. Entezam, A.; Biacsi, R.; Orrison, B.; Saha, T.; Hoffman, G.E.; Grabczyk, E.; Nussbaum, R.L.; Usdin, K. Regional FMRP deficits and large repeat expansions into the full mutation range in a new Fragile X premutation mouse model. Gene 2007, 395, 125-134. [CrossRef]

73. Jonson, I.; Ougland, R.; Klungland, A.; Larsen, E. Oxidative stress causes DNA triplet expansion in Huntington's disease mouse embryonic stem cells. Stem Cell Res. 2013, 11, 1264-1271. [CrossRef] [PubMed]

74. Budworth, H.; Harris, F.R.; Williams, P.; Lee, D.Y.; Holt, A.; Pahnke, J.; Szczesny, B.; Acevedo-Torres, K.; Ayala-Pena, S.; McMurray, C.T. Suppression of Somatic Expansion Delays the Onset of Pathophysiology in a Mouse Model of Huntington's Disease. PLoS Genet. 2015, 11, e1005267. [CrossRef] [PubMed]

75. Mollersen, L.; Moldestad, O.; Rowe, A.D.; Bjolgerud, A.; Holm, I.; Tveteras, L.; Klungland, A.; Retterstol, L. Effects of Anthocyanins on CAG Repeat Instability and Behaviour in Huntington's Disease R6/1 Mice. PLoS Curr. 2016, 8. [CrossRef] [PubMed]

76. Lokanga, R.A.; Zhao, X.N.; Entezam, A.; Usdin, K. X inactivation plays a major role in the gender bias in somatic expansion in a mouse model of the fragile X-related disorders: Implications for the mechanism of repeat expansion. Hum. Mol. Genet. 2014, 23, 4985-4994. [CrossRef]

77. Kovtun, I.V.; Liu, Y.; Bjoras, M.; Klungland, A.; Wilson, S.H.; McMurray, C.T. OGG1 initiates age-dependent CAG trinucleotide expansion in somatic cells. Nature 2007, 447, 447-452. [CrossRef]

78. Lokanga, R.A.; Senejani, A.G.; Sweasy, J.B.; Usdin, K. Heterozygosity for a hypomorphic Polbeta mutation reduces the expansion frequency in a mouse model of the Fragile X-related disorders. PLoS Genet. 2015, 11, e1005181. [CrossRef]

79. Lokanga, R.A.; Zhao, X.N.; Usdin, K. The mismatch repair protein MSH2 is rate limiting for repeat expansion in a fragile $\mathrm{X}$ premutation mouse model. Hum. Mutat. 2014, 35, 129-136. [CrossRef]

80. Miller, C.J.; Kim, G.Y.; Zhao, X.; Usdin, K. All three mammalian MutL complexes are required for repeat expansion in a mouse cell model of the Fragile X-related disorders. PLoS Genet 2020, 16, e1008902. [CrossRef]

81. Zhao, X.; Zhang, Y.; Wilkins, K.; Edelmann, W.; Usdin, K. MutLgamma promotes repeat expansion in a Fragile X mouse model while EXO1 is protective. PLoS Genet. 2018, 14, e1007719. [CrossRef]

82. Zhao, X.N.; Kumari, D.; Gupta, S.; Wu, D.; Evanitsky, M.; Yang, W.; Usdin, K. Mutsbeta generates both expansions and contractions in a mouse model of the Fragile X-associated disorders. Hum. Mol. Genet. 2015, 24, 7087-7096. [CrossRef]

83. Gazy, I.; Hayward, B.; Potapova, S.; Zhao, X.; Usdin, K. Double-strand break repair plays a role in repeat instability in a fragile X mouse model. DNA Repair (Amst) 2019, 74, 63-69. [CrossRef]

84. Sellier, C.; Freyermuth, F.; Tabet, R.; Tran, T.; He, F.; Ruffenach, F.; Alunni, V.; Moine, H.; Thibault, C.; Page, A.; et al. Sequestration of DROSHA and DGCR8 by expanded CGG RNA repeats alters microRNA processing in fragile X-associated tremor/ataxia syndrome. Cell Rep. 2013, 3, 869-880. [CrossRef] [PubMed]

85. Todd, P.K.; Oh, S.Y.; Krans, A.; He, F.; Sellier, C.; Frazer, M.; Renoux, A.J.; Chen, K.C.; Scaglione, K.M.; Basrur, V.; et al. CGG repeat-associated translation mediates neurodegeneration in fragile $X$ tremor ataxia syndrome. Neuron 2013, 78, 440-455. [CrossRef]

86. Oh, S.Y.; He, F.; Krans, A.; Frazer, M.; Taylor, J.P.; Paulson, H.L.; Todd, P.K. RAN translation at CGG repeats induces ubiquitin proteasome system impairment in models of fragile X-associated tremor ataxia syndrome. Hum. Mol. Genet. 2015, 24, 4317-4326. [CrossRef]

87. Nguyen, L.; Cleary, J.D.; Ranum, L.P.W. Repeat-Associated Non-ATG Translation: Molecular Mechanisms and Contribution to Neurological Disease. Annu. Rev. Neurosci. 2019, 42, 227-247. [CrossRef]

88. Skourti-Stathaki, K.; Torlai Triglia, E.; Warburton, M.; Voigt, P.; Bird, A.; Pombo, A. R-Loops Enhance Polycomb Repression at a Subset of Developmental Regulator Genes. Mol. Cell 2019, 73, 930-945.e934. [CrossRef] [PubMed]

89. Skourti-Stathaki, K.; Kamieniarz-Gdula, K.; Proudfoot, N.J. R-loops induce repressive chromatin marks over mammalian gene terminators. Nature 2014, 516, 436-439. [CrossRef] [PubMed]

90. Garribba, L.; Bjerregaard, V.A.; Goncalves Dinis, M.M.; Ozer, O.; Wu, W.; Sakellariou, D.; Pena-Diaz, J.; Hickson, I.D.; Liu, Y. Folate stress induces SLX1- and RAD51-dependent mitotic DNA synthesis at the fragile X locus in human cells. Proc. Natl. Acad. Sci. USA 2020, 117, 16527-16536. [CrossRef]

91. Hayward, B.E.; Steinbach, P.J.; Usdin, K. A point mutation in the nuclease domain of MLH3 eliminates repeat expansions in a mouse stem cell model of the Fragile X-related disorders. Nucleic Acids Res. 2020, 48, 7856-7863. [CrossRef]

92. Kadyrova, L.Y.; Gujar, V.; Burdett, V.; Modrich, P.L.; Kadyrov, F.A. Human MutLgamma, the MLH1-MLH3 heterodimer, is an endonuclease that promotes DNA expansion. Proc. Natl. Acad. Sci. USA 2020, 117, 3535-3542. [CrossRef]

93. Handa, V.; Goldwater, D.; Stiles, D.; Cam, M.; Poy, G.; Kumari, D.; Usdin, K. Long CGG-repeat tracts are toxic to human cells: Implications for carriers of Fragile X premutation alleles. FEBS Lett. 2005, 579, 2702-2708. [CrossRef] [PubMed] 
94. Jin, P.; Zarnescu, D.C.; Zhang, F.; Pearson, C.E.; Lucchesi, J.C.; Moses, K.; Warren, S.T. RNA-mediated neurodegeneration caused by the fragile $X$ premutation rCGG repeats in Drosophila. Neuron 2003, 39, 739-747. [CrossRef]

95. Willemsen, R.; Hoogeveen-Westerveld, M.; Reis, S.; Holstege, J.; Severijnen, L.A.; Nieuwenhuizen, I.M.; Schrier, M.; van Unen, L.; Tassone, F.; Hoogeveen, A.T.; et al. The FMR1 CGG repeat mouse displays ubiquitin-positive intranuclear neuronal inclusions; implications for the cerebellar tremor/ataxia syndrome. Hum. Mol. Genet. 2003, 12, 949-959. [CrossRef] [PubMed]

96. Hashem, V.; Galloway, J.N.; Mori, M.; Willemsen, R.; Oostra, B.A.; Paylor, R.; Nelson, D.L. Ectopic expression of CGG containing mRNA is neurotoxic in mammals. Hum. Mol. Genet. 2009, 18, 2443-2451. [CrossRef]

97. Hoem, G.; Raske, C.R.; Garcia-Arocena, D.; Tassone, F.; Sanchez, E.; Ludwig, A.L.; Iwahashi, C.K.; Kumar, M.; Yang, J.E.; Hagerman, P.J. CGG-repeat length threshold for FMR1 RNA pathogenesis in a cellular model for FXTAS. Hum. Mol. Genet. 2011, 20, 2161-2170. [CrossRef]

98. Greco, C.M.; Hagerman, R.J.; Tassone, F.; Chudley, A.E.; Del Bigio, M.R.; Jacquemont, S.; Leehey, M.; Hagerman, P.J. Neuronal intranuclear inclusions in a new cerebellar tremor/ataxia syndrome among fragile $X$ carriers. Brain 2002, 125, 1760-1771. [CrossRef]

99. Tassone, F.; Iwahashi, C.; Hagerman, P.J. FMR1 RNA within the intranuclear inclusions of fragile X-associated tremor/ataxia syndrome (FXTAS). RNA Biol. 2004, 1, 103-105. [CrossRef]

100. Powell, W.T.; Coulson, R.L.; Gonzales, M.L.; Crary, F.K.; Wong, S.S.; Adams, S.; Ach, R.A.; Tsang, P.; Yamada, N.A.; Yasui, D.H.; et al. R-loop formation at Snord116 mediates topotecan inhibition of Ube3a-antisense and allele-specific chromatin decondensation. Proc. Natl. Acad. Sci. USA 2013, 110, 13938-13943. [CrossRef]

101. Ginno, P.A.; Lott, P.L.; Christensen, H.C.; Korf, I.; Chedin, F. R-loop formation is a distinctive characteristic of unmethylated human CpG island promoters. Mol. Cell 2012, 45, 814-825. [CrossRef]

102. Arab, K.; Karaulanov, E.; Musheev, M.; Trnka, P.; Schafer, A.; Grummt, I.; Niehrs, C. GADD45A binds R-loops and recruits TET1 to CpG island promoters. Nat. Genet. 2019, 51, 217-223. [CrossRef] [PubMed]

103. Redstone, S.C.J.; Fleming, A.M.; Burrows, C.J. Oxidative Modification of the Potential G-Quadruplex Sequence in the PCNA Gene Promoter Can Turn on Transcription. Chem. Res. Toxicol. 2019, 32, 437-446. [CrossRef]

104. Sellier, C.; Rau, F.; Liu, Y.; Tassone, F.; Hukema, R.K.; Gattoni, R.; Schneider, A.; Richard, S.; Willemsen, R.; Elliott, D.J.; et al Sam68 sequestration and partial loss of function are associated with splicing alterations in FXTAS patients. EMBO J. 2010, 29, 1248-1261. [CrossRef] [PubMed]

105. Kearse, M.G.; Green, K.M.; Krans, A.; Rodriguez, C.M.; Linsalata, A.E.; Goldstrohm, A.C.; Todd, P.K. CGG Repeat-Associated Non-AUG Translation Utilizes a Cap-Dependent Scanning Mechanism of Initiation to Produce Toxic Proteins. Mol. Cell 2016, 62, 314-322. [CrossRef]

106. Krans, A.; Kearse, M.G.; Todd, P.K. Repeat-associated non-AUG translation from antisense CCG repeats in fragile X tremor/ataxia syndrome. Ann. Neurol. 2016, 80, 871-881. [CrossRef] [PubMed]

107. Sellier, C.; Buijsen, R.A.M.; He, F.; Natla, S.; Jung, L.; Tropel, P.; Gaucherot, A.; Jacobs, H.; Meziane, H.; Vincent, A.; et al. Translation of Expanded CGG Repeats into FMRpolyG Is Pathogenic and May Contribute to Fragile X Tremor Ataxia Syndrome. Neuron 2017, 93, 331-347. [CrossRef]

108. Kozak, M. Evaluation of the fidelity of initiation of translation in reticulocyte lysates from commercial sources. Nucleic Acids Res. 1990, 18, 2828. [CrossRef]

109. Krans, A.; Skariah, G.; Zhang, Y.; Bayly, B.; Todd, P.K. Neuropathology of RAN translation proteins in fragile X-associated tremor/ataxia syndrome. Acta Neuropathol. Commun. 2019, 7, 152. [CrossRef]

110. Bonapace, G.; Gullace, R.; Concolino, D.; Iannello, G.; Procopio, R.; Gagliardi, M.; Arabia, G.; Barbagallo, G.; Lupo, A.; Manfredini, L.I.; et al. Intracellular FMRpolyG-Hsp70 complex in fibroblast cells from a patient affected by fragile $\mathrm{X}$ tremor ataxia syndrome. Heliyon 2019, 5, e01954. [CrossRef] [PubMed]

111. Buijsen, R.A.; Sellier, C.; Severijnen, L.A.; Oulad-Abdelghani, M.; Verhagen, R.F.; Berman, R.F.; Charlet-Berguerand, N.; Willemsen, R.; Hukema, R.K. FMRpolyG-positive inclusions in CNS and non-CNS organs of a fragile X premutation carrier with fragile X-associated tremor/ataxia syndrome. Acta Neuropathol. Commun. 2014, 2, 162. [CrossRef]

112. Friedman-Gohas, M.; Elizur, S.E.; Dratviman-Storobinsky, O.; Aizer, A.; Haas, J.; Raanani, H.; Orvieto, R.; Cohen, Y. FMRpolyG accumulates in FMR1 premutation granulosa cells. J. Ovarian Res. 2020, 13, 22. [CrossRef]

113. Tian, B.; White, R.J.; Xia, T.; Welle, S.; Turner, D.H.; Mathews, M.B.; Thornton, C.A. Expanded CUG repeat RNAs form hairpins that activate the double-stranded RNA-dependent protein kinase PKR. RNA 2000, 6, 79-87. [CrossRef] [PubMed]

114. Zu, T.; Guo, S.; Bardhi, O.; Ryskamp, D.A.; Li, J.; Khoramian Tusi, S.; Engelbrecht, A.; Klippel, K.; Chakrabarty, P.; Nguyen, L.; et al. Metformin inhibits RAN translation through PKR pathway and mitigates disease in C9orf72 ALS/FTD mice. Proc. Natl. Acad. Sci. USA 2020, 117, 18591-18599. [CrossRef] [PubMed]

115. Green, K.M.; Glineburg, M.R.; Kearse, M.G.; Flores, B.N.; Linsalata, A.E.; Fedak, S.J.; Goldstrohm, A.C.; Barmada, S.J.; Todd, P.K. RAN translation at C9orf72-associated repeat expansions is selectively enhanced by the integrated stress response. Nat. Commun. 2017, 8, 2005. [CrossRef] [PubMed]

116. Haify, S.N.; Mankoe, R.S.D.; Boumeester, V.; van der Toorn, E.C.; Verhagen, R.F.M.; Willemsen, R.; Hukema, R.K.; Bosman, L.W.J. Lack of a Clear Behavioral Phenotype in an Inducible FXTAS Mouse Model Despite the Presence of Neuronal FMRpolyG-Positive Aggregates. Front. Mol. Biosci. 2020, 7, 599101. [CrossRef] 
117. Holm, K.N.; Herren, A.W.; Taylor, S.L.; Randol, J.L.; Kim, K.; Espinal, G.; Martiinez-Cerdeno, V.; Pessah, I.N.; Hagerman, R.J.; Hagerman, P.J. Human Cerebral Cortex Proteome of Fragile X-Associated Tremor/Ataxia Syndrome. Front. Mol. Biosci. 2020, 7 , 600840. [CrossRef]

118. Rodriguez, S.; Sahin, A.; Schrank, B.R.; Al-Lawati, H.; Costantino, I.; Benz, E.; Fard, D.; Albers, A.D.; Cao, L.; Gomez, A.C.; et al. Genome-encoded cytoplasmic double-stranded RNAs, found in C9ORF72 ALS-FTD brain, propagate neuronal loss. Sci. Transl. Med. 2021, 13. [CrossRef]

119. Cabal-Herrera, A.M.; Tassanakijpanich, N.; Salcedo-Arellano, M.J.; Hagerman, R.J. Fragile X-Associated Tremor / Ataxia Syndrome (FXTAS): Pathophysiology and Clinical Implications. Int. J. Mol. Sci. 2020, 21, 4391. [CrossRef]

120. Cristini, A.; Ricci, G.; Britton, S.; Salimbeni, S.; Huang, S.N.; Marinello, J.; Calsou, P.; Pommier, Y.; Favre, G.; Capranico, G.; et al. Dual Processing of R-Loops and Topoisomerase I Induces Transcription-Dependent DNA Double-Strand Breaks. Cell Rep. 2019, 28, 3167-3181.e3166. [CrossRef]

121. Crossley, M.P.; Bocek, M.; Cimprich, K.A. R-Loops as Cellular Regulators and Genomic Threats. Mol. Cell 2019, 73, $398-411$. [CrossRef] [PubMed]

122. Primerano, B.; Tassone, F.; Hagerman, R.J.; Hagerman, P.; Amaldi, F.; Bagni, C. Reduced FMR1 mRNA translation efficiency in fragile X patients with premutations. RNA 2002, 8, 1482-1488. [PubMed]

123. Schneider, A.; Winarni, T.I.; Cabal-Herrera, A.M.; Bacalman, S.; Gane, L.; Hagerman, P.; Tassone, F.; Hagerman, R. Elevated FMR1-mRNA and lowered FMRP-A double-hit mechanism for psychiatric features in men with FMR1 premutations. Transl. Psychiatry 2020, 10, 205. [CrossRef] [PubMed]

124. Feng, Y.; Zhang, F.; Lokey, L.K.; Chastain, J.L.; Lakkis, L.; Eberhart, D.; Warren, S.T. Translational suppression by trinucleotide repeat expansion at FMR1. Science 1995, 268, 731-734. [CrossRef] [PubMed]

125. Kumari, D.; Usdin, K. Polycomb group complexes are recruited to reactivated FMR1 alleles in Fragile X syndrome in response to FMR1 transcription. Hum. Mol. Genet. 2014, 23, 6575-6583. [CrossRef]

126. Alecki, C.; Chiwara, V.; Sanz, L.A.; Grau, D.; Arias Perez, O.; Boulier, E.L.; Armache, K.J.; Chedin, F.; Francis, N.J. RNA-DNA strand exchange by the Drosophila Polycomb complex PRC2. Nat. Commun. 2020, 11, 1781. [CrossRef]

127. Wang, X.; Goodrich, K.J.; Gooding, A.R.; Naeem, H.; Archer, S.; Paucek, R.D.; Youmans, D.T.; Cech, T.R.; Davidovich, C. Targeting of Polycomb Repressive Complex 2 to RNA by Short Repeats of Consecutive Guanines. Mol. Cell 2017, 65, 1056-1067.e1055. [CrossRef]

128. Jani, K.S.; Jain, S.U.; Ge, E.J.; Diehl, K.L.; Lundgren, S.M.; Muller, M.M.; Lewis, P.W.; Muir, T.W. Histone H3 tail binds a unique sensing pocket in EZH2 to activate the PRC2 methyltransferase. Proc. Natl. Acad. Sci. USA 2019, 116, 8295-8300. [CrossRef]

129. Yuan, W.; Xu, M.; Huang, C.; Liu, N.; Chen, S.; Zhu, B. H3K36 methylation antagonizes PRC2-mediated H3K27 methylation. J. Biol. Chem. 2011, 286, 7983-7989. [CrossRef]

130. Schmitges, F.W.; Prusty, A.B.; Faty, M.; Stutzer, A.; Lingaraju, G.M.; Aiwazian, J.; Sack, R.; Hess, D.; Li, L.; Zhou, S.; et al. Histone methylation by PRC2 is inhibited by active chromatin marks. Mol. Cell 2011, 42, 330-341. [CrossRef]

131. Huertas, P.; Aguilera, A. Cotranscriptionally formed DNA:RNA hybrids mediate transcription elongation impairment and transcription-associated recombination. Mol. Cell 2003, 12, 711-721. [CrossRef]

132. Shanbhag, N.M.; Rafalska-Metcalf, I.U.; Balane-Bolivar, C.; Janicki, S.M.; Greenberg, R.A. ATM-dependent chromatin changes silence transcription in cis to DNA double-strand breaks. Cell 2010, 141, 970-981. [CrossRef]

133. Pankotai, T.; Bonhomme, C.; Chen, D.; Soutoglou, E. DNAPKcs-dependent arrest of RNA polymerase II transcription in the presence of DNA breaks. Nat. Struct. Mol. Biol. 2012, 19, 276-282. [CrossRef]

134. Zhou, Y.; Kumari, D.; Sciascia, N.; Usdin, K. CGG-repeat dynamics and FMR1 gene silencing in fragile X syndrome stem cells and stem cell-derived neurons. Mol. Autism 2016, 7, 42. [CrossRef]

135. Niehrs, C.; Luke, B. Regulatory R-loops as facilitators of gene expression and genome stability. Nat. Rev. Mol. Cell Biol. 2020, 21, 167-178. [CrossRef] [PubMed]

136. Hecht, M.; Tabib, A.; Kahan, T.; Orlanski, S.; Gropp, M.; Tabach, Y.; Yanuka, O.; Benvenisty, N.; Keshet, I.; Cedar, H. Epigenetic mechanism of FMR1 inactivation in Fragile X syndrome. Int. J. Dev. Biol. 2017, 61, 285-292. [CrossRef] [PubMed]

137. Ladd, P.D.; Smith, L.E.; Rabaia, N.A.; Moore, J.M.; Georges, S.A.; Hansen, R.S.; Hagerman, R.J.; Tassone, F.; Tapscott, S.J.; Filippova, G.N. An antisense transcript spanning the CGG repeat region of FMR1 is upregulated in premutation carriers but silenced in full mutation individuals. Hum. Mol. Genet. 2007, 16, 3174-3187. [CrossRef] [PubMed]

138. Kumari, D.; Sciascia, N.; Usdin, K. Small Molecules Targeting H3K9 Methylation Prevent Silencing of Reactivated FMR1 Alleles in Fragile X Syndrome Patient Derived Cells. Genes 2020, 11, 356. [CrossRef] [PubMed]

139. Lukusa, T.; Fryns, J.P. Human chromosome fragility. Biochim. Biophys. Acta 2008, 1779, 3-16. [CrossRef]

140. Sutherland, G.R. Heritable fragile sites on human chromosomes. III. Detection of fra(X)(q27) in males with X-linked mental retardation and in their female relatives. Hum. Genet. 1979, 53, 23-27. [CrossRef]

141. Voineagu, I.; Surka, C.F.; Shishkin, A.A.; Krasilnikova, M.M.; Mirkin, S.M. Replisome stalling and stabilization at CGG repeats, which are responsible for chromosomal fragility. Nat. Struct. Mol. Biol. 2009, 16, 226-228. [CrossRef] [PubMed]

142. Gerhardt, J.; Tomishima, M.J.; Zaninovic, N.; Colak, D.; Yan, Z.; Zhan, Q.; Rosenwaks, Z.; Jaffrey, S.R.; Schildkraut, C.L. The DNA replication program is altered at the FMR1 locus in fragile X embryonic stem cells. Mol. Cell 2014, 53, 19-31. [CrossRef] 
143. Derbis, M.; Kul, E.; Niewiadomska, D.; Sekrecki, M.; Piasecka, A.; Taylor, K.; Hukema, R.K.; Stork, O.; Sobczak, K. Short antisense oligonucleotides alleviate the pleiotropic toxicity of RNA harboring expanded CGG repeats. Nat. Commun. 2021, $12,1265$. [CrossRef] [PubMed]

144. Disney, M.D.; Liu, B.; Yang, W.Y.; Sellier, C.; Tran, T.; Charlet-Berguerand, N.; Childs-Disney, J.L. A small molecule that targets $\mathrm{r}(\mathrm{CGG})(\mathrm{exp})$ and improves defects in fragile X-associated tremor ataxia syndrome. ACS Chem. Biol. 2012, 7, 1711-1718. [CrossRef] [PubMed]

145. Verma, A.K.; Khan, E.; Mishra, S.K.; Mishra, A.; Charlet-Berguerand, N.; Kumar, A. Curcumin Regulates the r(CGG)(exp) RNA Hairpin Structure and Ameliorate Defects in Fragile X-Associated Tremor Ataxia Syndrome. Front. Neurosci. $2020,14,295$. [CrossRef]

146. Haify, S.N.; Buijsen, R.A.M.; Verwegen, L.; Severijnen, L.; de Boer, H.; Boumeester, V.; Monshouwer, R.; Yang, W.Y.; Cameron, M.D.; Willemsen, R.; et al. Small molecule 1a reduces FMRpolyG-mediated toxicity in in vitro and in vivo models for FMR1 premutation. Hum. Mol. Genet. 2021. [CrossRef] 